\title{
Public-Academic Library Cooperation
}

The author examines the legal and structural arrangements for publicacademic library cooperation. Rhode Island's program illustrates the problems involved as well as the importance of the role of the state library agency in successfully establishing cooperative programs.

C OOOPERATION BETWEEN academic and public libraries has been a topic of professional discussion for a long time. The merits and demerits have been debated, and while there is little point to rehashing all that has been said, it does seem worthwhile to review some new and some older attitudes.

The public librarian looks at P.L. 480 and the shared cataloging program of the Library of Congress and approves even though the benefits of these programs accrue chiefly to research and academic libraries. The public librarian looks at the Higher Education Act with its money for college libraries-books and buildings-and also approves. Then on Saturday, or at night, or during school vacations, the public librarian observes the college students doing papers, using the public library's meager resources, and pressing the library staff to find more information; it is then that he wonders how he can do any more.

The academic librarian, faced by the increasing difficulty of obtaining more and more money, finds it difficult to serve his own clientele; he does not need more people from outside the campus demanding service. The academic library, experiencing the impact of growing enrollment and expanding college pro-

Mr. Healey is Assistant Professor in the Graduate Library School, University of Rhode Island. grams, finds itself "running fast just to stand still.” Josey, writing in 1967 about the attitudes of academic librarians toward community use, said, "Being associated with a small college library, I readily understand some of the reasons for these attitudes; they often stem from small budgets that do not meet minimal needs of service for campus clientele, that do not permit adequate staffs, and that do not allow space to accommodate 'outsiders.' "1

But the public librarian, rebuffed and helpless to satisfy the growing information needs of a public whose educational level climbs each year, knows frustration and asks, "How can the academic libraries be given so much-from my tax dollars-and give so little in return?" Again, from Josey: "More recently, academic libraries are accepting federal assistance, not only for building construction, but also for books, materials and equipment. The question of whether or not to deny a taxpayer the right to use his tax dollar in a given academic library may no longer be moot." In an editorial on access to libraries, Eric Moon wrote: "Could not non-residents argue that they had a right of free access to libraries receiving generous support from state and federal funds to which their taxes had contributed?" Could we not rephrase Moon's question to read: "Could not the residents of the community argue that they had a right 
of free access to college and university libraries receiving generous support from state and federal funds to which their taxes had contributed?"2 Despite the divergent needs and views cooperative programs have been undertaken. To bring the academic and public library together there are some basic factors that must be observed and some ways of bypassing many of the inhibiting aspects that cooperation between disparate agencies inherently fosters.

Logsdon and Nelson, writing in 1965, laid down some guidelines for effective cooperation. Their list included: “1) Cooperation is not good in itself, it is a voluntary act which must be pursued creatively and geared to local situations; 2) Objective appraisal of the results of cooperation is as critical as advance planning and sound implementation; 3 ) Cooperation must take into account the legitimate ambitions as well as the present status of the individual cooperating institution; 4) A precondition to an effective system of interlocking libraries is the creation of an adequate governmental structure to develop and sustain it" (italics mine). ${ }^{3}$ The authors were writing of cooperation between academic libraries, but their guidelines are equally applicable to cooperation between types of libraries. In that context, when the authors speak of "The present status of the individual cooperating institutions," one could interpret this to mean that public libraries should be public libraries and academic libraries should be academic libraries. Since each type of library has a very well-defined role to play, mixing or switching roles would seem to be an inhibiting factor in the performance of any role at all. Martin's two studies of Pennsylvania library systems bear this out. In his first study in 1958, he advocated using college libraries as regional centers where no public libraries could perform the task. In his follow-up study in 1967, Martin found that while the idea was sound in theory, it had not proved very effective in practice. ${ }^{4}$

Another aspect of the Logsdon-Nelson article deals with structure. Any attempt to establish cooperative ventures without substantial attention being paid to the role, responsibilities, and rights of the libraries involved and how the libraries will interact begins at a disadvantage. In the past the problem of who shall do the structuring has been a difficult one; neither type of library generally is willing to have its role or function designated by the other agency. Equally important is the question of who will take the lead in establishing such a program of interlibrary cooperation?

Prentiss states: "Although library networks can, and do, rest on every conceivable type of base, there are several reasons why a state is one of the more satisfactory bases for many networks. For example: (1) it hardly seems necessary to point out that moving to the state level automatically and painlessly eliminates innumerable minor civil boundaries, each of which would otherwise constitute a barrier to free library use; (2) most states are large enough to serve as a base for most network purposes; (3) states are a potential source of fiscal support, with revenues which are not available to political subdivisions below the state level; and (4) state library agencies have a leadership potential that cuts across types of libraries, all varieties of library interests, and all levels of government below the federal." "5

On consulting Purdy's article, "Interrelations among Public, School and Academic Libraries," one finds a fairly comprehensive overview of the number and kinds of such statewide programs already in action. ${ }^{6}$ These points serve as the basis for what follows. Rhode Island's program of statewide interlibrary cooperation embodies most of the ideas expressed up to this point and also illustrates one way of involving state and private universities.

The Rhode Island library folklore is 
that the present program originated with a Brown University professor of Education who was extremely dissatisfied with his child's school library. Because of his dissatisfaction, the professor did some checking on his own. Finding the entire state's school systems distressingly poor in library resources, he prevailed upon Brown University to sponsor a study of the library resources of the state.

However heartwarming the tale and whatever the motivation, Brown University did in fact propose a study, which was conducted between October 1960 and March 1962 and funded by the Council on Library Resources, Inc. John A. Humphry (then director of the Springfield, Massachusetts, library) was appointed to conduct the survey. The results of the study were published under the title, Library Cooperation, by Brown University in $1963 .^{7}$ The results of that survey have been quite far-reaching, for from its recommendations came the Rhode Island State Department of Library Services, a program of state aid to libraries, and the Graduate Library School at the University of Rhode Island.

Humphry's recommendations in the area of academic participation in services to noncollege personnel were quite specific:

... That the extensive and unusual library resources of Brown University, be made more widely available, and that the State reimburse the University for such services.

...

Consideration should be given to designating the University [of Rhode Island] Library an additional library resource center for the residents of southern Rhode Island. ... .

The Brown University Library shall be reimbursed annually for providing research facilities for faculty and graduate students in other academic institutions in Rhode Island and others engaged in advanced study and research not connected with an institution of higher learning. ... .
These and other institutions of higher learning in Rhode Island have the common purpose of educating young people. While the emphasis in each will be different, depending upon its specific objectives, there is a basic collection of materials which each institution must provide for its own students. Further cooperation is recommended among the public and private institutions of higher learning, including the private libraries. ${ }^{8}$

Following the publication of the report, the Rhode Island legislature created a study committee to frame recommendations, which were included in a bill which became state law in 1964. Of particular importance was the planned inclusion of the Brown and Rhode Island University libraries and the Rhode Island College library as part of the statewide program from the outset.

Special research centers.-The department of state library services is hereby authorized to designate certain other libraries, such as those at Brown University, the University of Rhode Island, and Rhode Island College, as "special research centers," the special collections of which are available for research in particular fields of knowledge. A special research center so designated shall be eligible for an annual grant-in-aid in an amount to be determined by the director of state library services on condition that such special research center so designated enter into an appropriate agreement with the department of state library services to act as such special research center in accordance with regulations to be made by the director of state library services pursuant to the provisions of 29-3.1-5 of the general laws. ${ }^{9}$

Rhode Island's program for academicpublic library cooperation was thus established on a basis of law. This settled most of the legal aspects of agreements before the program became operational. It is in large measure because of the formality of agreements that the program has moved forward with relatively few major problems.

The kinds of services provided cover 
a fairly wide range. The chief focus of the academic library participation is on interlibrary loan and the use of books in the academic libraries by those who are not members of that particular academic community or by those who are not connected with any academic community. Requests are transmitted from the local library to the regional library over the telephone. Unfilled requests are then transmitted over the state agency-funded TWX system, which includes the other regional and academic libraries as well as the Providen e Public Library. If these agencies cannot supply the material needed, the Providence Public Library decides where the request will be sent next; this generally results in the request being sent to one of the public academic institutions, again over TWX. The Brown University Library is called upon for very advanced or highly specialized materials.

Tied to the interlibrary loan program is an agreement to supply photocopies of journal articles or monograph pages. The number of copies varies with the library; each agency is supposed to provide up to ten pages free with the understanding that this is one way the agency "earns" its grant. While a limit is offcially set, individual libraries tend to disregard the letter of the law and provide up to a "reasonable number" (whatever that means).

A recent development, which has evolved from a program originally established to serve school and small public libraries, is a centralized processing operation. In summer 1967, a processing center was begun at the state headquarters in Providence. One function of the center is cataloging in the LC mode, although the Dewey system was originally used. In 1969, the state processing center began cataloging and processing books for the Roger Williams College Library and producing catalog card sets for the Brown University Library (both private institutions which classify and catalog their books according to LC practice).

The processing center will also provide an important benefit. There are approximately 33,000 monographic titles in the center's data banks. The entries developed from school and small public libraries have little usefulness for those with sophisticated informational needs. However, processing some of the materials of two academic libraries and one of the regional libraries will gradually alter the content of the data banks. With more advanced institutions involved, the data gathered will be of far more importance to the advanced information seeker. A union list of holdings is gradually being built.

Concurrently, but not presently connected with the statewide program, the University of Rhode Island participates in Project NELINET (New England Library Network). This program involves the six New England state universities and INFORONICS, INC. (a Boston-based, computer research organization), with the production of catalog hard copy from the MARC II tapes. Each university informs the company of the catalog information it wants over teletype and receives complete sets of materials to process the books. Because the University of Rhode Island is a member of the state regional system, it is not impossible to envision the processing center making use of the information received by URI through the NELINET program.

One of the least quantifiable aspects of the program has been the dialog between librarians. Until 1964, dialog among academic, school, and public librarians was minimal and generally limited to greetings at meetings. Presently, monthly system meetings are held; evaluation of services and problems, and discussion of new programs are topics of these meetings. A dialog has been established because of these monthly meetings and that dialog is one of the most 
important by-products of the entire program. The academic and public librarians have found much common ground through their discussion of similar problems. One interesting manifestation of this involvement can be seen in the following example. The state agency proposed a complete inventory of libraries within the state, and the proposal was seen as an inventory of all kinds of libraries-academic, public, special, and school. To make the inventory one survey team included staff members of the University of Rhode Island.

Another development has been the interest shown in the program by other academic institutions in the state, many of which are small colleges with small libraries. These libraries are interested because they can visualize the specific ways in which participation in the program will benefit their own clientele. As these libraries become more deeply involved, the use pattern that is expected to develop will, to some extent, lighten the load on the major institutions and broaden the materials base on which all can draw. The case of Bryant College, a school whose orientation was originally business, illustrates the benefits of involvement. It is now an accredited fouryear, liberal arts college, working to build its resources. While examining the feasibility of erecting one library building to serve three communities in northern Rhode Island, the author talked with the director of the Bryant College Library. He was enthusiastic in his desire to extend cooperative opportunities to those who would be served through interlibrary loan by the Area Library (as it was called) and the Pawtucket Regional Library (the regional library for northern Rhode Island), and was very interested in the area of cooperative acquisitions. ${ }^{10}$

There are other examples, but the point worth emphasizing is that the basic premises stated earlier do make con- crete and viable results possible when those premises are applied intelligently. Logsdon and Nelson's idea of structure is vital to the success of any program. Proper structuring does make it possible, feasible, and even attractive for the academic library to join its public counterpart in cooperative ventures. The academic library should not be expected to give without recompense, nor without knowing how much or what kind it will have to give. From the public library's standpoint, this structuring is equally important. With this kind of approach, the public library knows where it can go to fulfill its specialized requests, and it can use its own resources in various other ways.

Another basic purpose of this paper was to emphasize the role of the state agency in promoting interlibrary cooperation. Prentiss' observation that "state library agencies have a leadership potential that cuts across types of libraries, all varieties of library interests and all levels of government below the federal" is quite germane. The state agency can more easily effect the legal arrangements that are necessary to a program of interlibrary cooperation. The state agency, which has fewer of the traditional emotional impediments connected with this topic, can take a leading role. The state agency is probably the one agency that can promote dialog, both with the greatest ease and with the best chance of success. It can be argued that until the state agencies become politically and financially stronger, extensive and effective interlibrary cooperation cannot exist. Now it appears that the state agency is evolving or already has evolved to the point where it can creatively coordinate and direct, enabling both public and university libraries to be less concerned with the mechanics of cooperation and more concerned with the results. Such results should be welcomed by all. 


\section{REFERENCES}

1. E. J. Josey, "Implications for College Libraries," College \& Research Libraries 28 (3):199 (May 1967).

2. Ibid., p.201.

3. Richard Logsdon and Charles Nelson, "Cooperation: Pitfall or Panacea," Special Libraries 56 (8):571-75 (October 1965).

4. Lowell A. Martin, Library Service in Pennsylvania, Present and Proposed: A Survey, Harrisburg, Pennsylvania State Library, 1958; and Lowell A. Martin, Progress and Problems of Pennsylvania Libraries: A Re-Survey, Harrisburg, Pennsylvania State Library, 1967.

5. S. G. Prentiss, "Evaluation of the Li- brary System (New York)," Library Quarterly 39 (1):78-89 (January 1969).

6. G. Flint Purdy, "Interrelations Among Public, School and Academic Libraries," Library Quarterly 39 (1):52-77 (January 1969).

7. John A. Humphry and Lucille Wickersham, Library Cooperation, Providence, R.I.: Brown University, 1963.

8. Ibid., p.117, 121, 134-35.

9. Rhode Island Library Laws, Chapter 6, "State Aid to Libraries," Section 29$6-9 ; \mathrm{p} .22$.

10. James S. Healey, "A Feasibility Study of an Area Library to Serve Northern Rhode Island," p.23 (manuscript) (August 1969). 